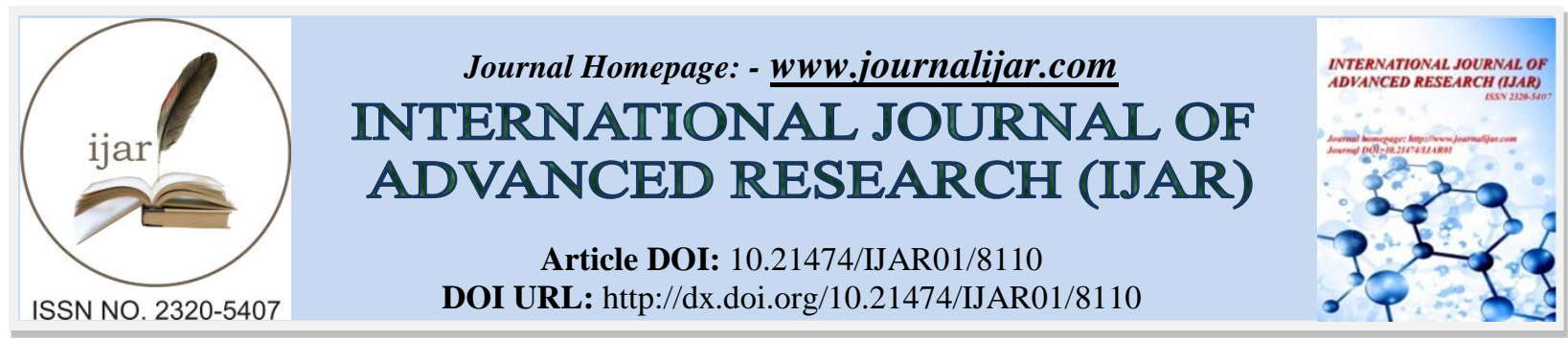

RESEARCH ARTICLE

\title{
REMOVAL OF PHOSPHATE IONS IN WASTEWATER BY COUPLING CHEMICAL TREATMENT- ACTIVATED CARBON TREATMENT: CASE OF AN URBAN WASTEWATER OF THE CITY OF YAMOUSSOUKRO (COTE D'IVOIRE).
}

Zran e. ${ }^{1}$, Yobouet $a^{2}{ }^{2}$, Trokourey $\mathbf{a}^{1}$, Yao $\mathbf{b}^{2}$ and Drogui $\mathbf{p}^{3}$.

1. UFR-Sciences des Structures de la Matière et de Technologie, Université de Félix HOUPHOUET-BOIGNY. Laboratoire de Chimie Physique, 22 BP. 582, Abidjan 22 (Côte d'Ivoire).

2. Institut National Polytechnique Félix HOUPHOUET-BOIGNY, Laboratoire de Procédés Industriels, de Synthèse, de l'Environnement, et des Energies Nouvelles, Groupe des Procédés et Environnement, BP. 1093, Yamoussoukro Côte d'Ivoire.

3. Institut National de la Recherche Scientifique. Département INRS-Eau Terre et Environnement, Université du Québec, 490 rue de la Couronne, Québec, QC G1K 9A9, Canada.

\section{Manuscript Info}

Manuscript History

Received: 01 October 2018

Final Accepted: 03 November 2018

Published: December 2018

Keywords:

Adsorbent. Removal rate. Eutrophication. Activated Carbon. Coprecipitation. Phosphate.

\section{Abstract}

This study focuses on the removal of phosphate ions from the method of co-precipitation in wastewaters of the city of Yamoussoukro. She contributes to various methods of struggle against the " cancer " of surface waters which is eutrophication. The chemical treatment of wastewater allowed in an average reduction phosphate ion rate of $89.00 \%$. On the other hand, the elimination of phosphate ions with activated carbon (fresh coconut fiber) brought on average a small increase, of the order of $2.00 \%$. So a reduction rate in total phosphate ions of about $91.00 \%$ of the chemical treatment-activated carbon treatment coupling of this urban wastewater. The coupling activated carbon treatment with the method of co-precipitation of phosphate ions does not seem to give convincing results. We can assume that the precipitates contained apatite because all final $\mathrm{pH}$ are higher than 9 .

Copy Right, IJAR, 2018,. All rights reserved.

\section{Introduction:-}

Up to days no continent can disregard the impact of wastewaters on watercourses. Indeed, the discharge of untreated ones into watercourses generates various environmental problems, whose the most apparent is the eutrophication. In developed countries, these wastewaters are treated before they are discharged, unfortunately it is not the same case in developing countries such as Ivory Coast. To this end, for sustainable development, it is important to find methods of treatment in order to limit this " cancer " of surface waters. Furthermore the state of the art about this phenomenon makes it possible to accurately locate the fondamentals causes. This is the enrichment in minerals primarily phosphorus. Coprecipitation of phosphorus in the form phosphate appears to be an interesting approach (Montastruc, 2003; Cemagref, 2004; Youcef and Achour., 2005; Barbara and Jaroslaw., 2006; Battistoni et al., 2006; Lupa and al., 2008; Cordell and al., 2009; Del Nero and al., 2010; Hanhoun and al., 2011; Mary, 2011, Shintaro and al., 2012; Said, 2012, Zran and al., 2015; Youcef and al., 2014; Zran, 2015.

\section{Corresponding Author:-Zran e.}

Address:-ufr-sciences des structures de la matière et de technologie, université de félix houphouetboigny. Laboratoire de chimie physique, 22 bp. 582, abidjan 22 (côte d'ivoire). 
This work is the continuation of work done on synthetic water loaded with phosphate ions by Zran and al., in 2015. First, we applied the optimum conditions found by them on real wastewaters. Then, we used activated carbon in order to eliminate the residual phosphate ions after the chemical treatment (Kumar and al., 2010; Zhang and al., 2011; Zhou and al., 2012; Shanableh and al., 2013; Youcef and al., 2014). Finally, this study concluded with a comparison of the phosphate removal rate $(95.88 \pm 0.08) \%$ obtained by Zran and al., (2015), during the treatment of synthetic solution with those obtained during treatment of wasterwater.

\section{Material and methods:-}

\section{Sampling of wastewater}

Wastewaters used come from big gutters of the City of Yamoussoukro. Two kinds of water were treated. Unfiltered wastewaters and filtered wastewaters with filters of cellulose acetate. These filtered are recognized for their inhibitory effect. Before chemical treatment of the water, concentration of phosphate ions was measured, in order to know the initial concentration of these ions. This concentration is completed to $10 \mathrm{mg} / \mathrm{L}$ by the injection of potassium dihydrogenphosphate $\left(\mathrm{KH}_{2} \mathrm{PO}_{4}\right)$. The optimum conditions obtained during processing of the synthetic water was then applied. These wastewaters were treated the same day of collection, with the aim to better reduce the action of micro-organisms.

\section{Removal procedure of phosphate ions by chemical treatment}

At $\mathrm{pH}=8.41$, wastewaters were treated using $10,00 \mathrm{mg} / \mathrm{L}$ of iron (II) sulfate heptahydrate $\left(\mathrm{FeSO}_{4} .7 \mathrm{H}_{2} \mathrm{O}\right)(\mathrm{Fe}$ content $20.1 \% \mathrm{w} / \mathrm{w}$ basis provided by ACS analytical grade reagent, NY, USA company) and 97,07 mg/L and by simultaneously using calcium hydroxide $\left(\mathrm{Ca}(\mathrm{OH})_{2}\right)$. Molar ratios $\mathrm{Ca} / \mathrm{P}$ and $\mathrm{Fe} / \mathrm{P}$ determined in the optimal conditions are the following: $\mathrm{Fe} / \mathrm{P}=0.34$ and $\mathrm{Ca} / \mathrm{P}=12.5$. Experiments were carried out in a $500 \mathrm{~mL}$ tank $(\mathrm{Pyrex}$ glass) containing $200 \mathrm{~mL}$ of wastewaters that was mixed using a jar-test system. The mixture was firstly stirred at $150 \mathrm{rpm}$ during $3 \mathrm{~min}$, followed by a $30 \mathrm{~min}$ stirring under $30 \mathrm{rpm}$. After $33 \mathrm{~min}$ of treatment, the mixture was subjected to settling for $1 \mathrm{~h}$. Once the separation of metallic sludge occurred $(1 \mathrm{~h})$, a fraction of the supernatant was recovered for $\mathrm{pH}$ and residual phosphorus concentration analysis. The residual phosphate concentration was used to calculate the removal rate according to Eq. (1):

$$
\text { Removal rate }(\%)=\frac{C_{0}-C_{1}}{C_{0}} \times 100
$$

With; $C_{0}=10 \mathrm{mg} / \mathrm{L}$ and $C_{l}$ : residual quantities of phosphate ions.

\section{Treatment of the wastewater with activated carbon}

The activated carbon used to refine the phosphate removal are derived from the fibrous mesocarp of coconut. The activated carbon was obtained by using the steps developed by Briton and al., (2006). This A.C. has a granulometry between 18.1 and $418.1 \AA$ and a specific surface of $315.4 \mathrm{~m}^{2} / \mathrm{g}$. The phosphate stripping tests were carried out batchwise on magnetic stirrers. This processing occurs after chemical pretreatment of the unfiltered and filtered water. Thus, $1 \mathrm{~g}$ of carbon powder is injected into $50 \mathrm{~mL}$ water after chemical treatment contained in a $100 \mathrm{~mL}$ beaker and stirred with a stirrer for one hour. The solid/liquid separation of taking the sample is carried out by vacuum filtration using a membrane of porosity $0.45 \mu \mathrm{m}$. For each sample filtered $\mathrm{pH}$ and the residual phosphate content were determined. The removal rate is calculated from Eq. 1.

\section{Results and discussion:-}

Examination of the composition of wastewater

Table 1 presents the mean with standard deviation and permitted value of parameters indicating characteristics of wastewater used. The average value results, in fact, several samples.

Examination of the results shows that this parameter of waste water is slightly polluted. Indeed, all the average values are below the thresholds of discharge standards values (CODINORM, 2009). However, this water is weakly alkaline $\mathrm{pH}$ as is $(7.46 \pm 0.10)$. This would promote the presence of ortho phosphate ions therein. The analysis of the mean $(1.43 \pm 0.06)$ phosphate ions indicates a low presence of these in the water.

Table 1:- Composition of wastewater and the maximum permitted (CODINORM, 2009) 


\begin{tabular}{|l|c|c|}
\hline Quality indicators & Average existing values & Permitted values \\
\hline $\mathrm{pH}$ & $(7.46 \pm 0.10)$ & $5.50 \leq \mathrm{pH} \leq 9.50$ \\
\hline Conductivity (in $\mu \mathrm{S} / \mathrm{Cm})$ & $(540 \pm 107.71)$ & $400.00-1500.00$ \\
\hline Turbidity (in NTU) & $(12.05 \pm 0.98)$ & 5.00 \\
\hline Temperature (in $\left.{ }^{\circ} \mathrm{C}\right)$ & $(24.35 \pm 3.39)$ & $\leq 30.00$ \\
\hline $\mathrm{TSM}$ (in mg/L) & $(13.50 \pm 095)$ & 150.00 \\
\hline $\mathrm{CCO}$ (in mg/L) & $(114.00 \pm 12)$ & 300.00 \\
\hline $\mathrm{BOD}$ (in mg/L) & $(37.85 \pm 7.09)$ & 150.00 \\
\hline $\mathrm{PO}_{4}{ }^{--}$(in mg/L) & $(1.43 \pm 0.06)$ & 5.00 \\
\hline $\mathrm{K}^{+}$(in mg/L) & $(36.12 \pm 8.12)$ & - \\
\hline $\mathrm{Cl}^{-}$(in mg/L) & $(55.88 \pm 16.28)$ & 5.00 \\
\hline $\mathrm{Ca}^{2+}$ (in mg/L) & $(60.61 \pm 25.48)$ & - \\
\hline $\mathrm{Fe}^{2+}($ in $\mathrm{mg} / \mathrm{L})$ & $(0.36 \pm 0.08)$ & 5.00 \\
\hline $\mathrm{SO}_{4}{ }^{2-}$ (in mg/L) & $(133.39 \pm 15.49)$ & 250.00 \\
\hline $\mathrm{Zn}^{2+}$ (in mg/L) & $(0.29 \pm 0.17)$ & 2.00 \\
\hline $\mathrm{Cu}^{2+}$ (in $\left.\mathrm{mg} / \mathrm{L}\right)$ & $(0.04 \pm 0.02)$ & 0.50 \\
\hline
\end{tabular}

\section{Analysis of the results of treatment unfiltered wastewater}

Chemical treatment

Examining results of the different phosphate removal rate of tests of table 2 shows that these rates are homogeneous. Indeed, the coefficient of variation $(\mathrm{C} . \mathrm{V} .=3.38 \%)$ related to phosphate removal rate after treatment is less than $5.00 \%$ (Feinberg, 1996).

Table 2 summarizes the results of the phosphate removal rate and the levels of COD, chloride ions and sulfate of the four tests before chemical treatment. The results of this table show low variability of phosphate removal rate with an average $(89.05 \pm 3.01) \%$, which indicates a phosphate removal up to $89.00 \%$, in the real matrix (wastewater). This is comparable with phosphate removal rate obtained during the work of Babara and Jaroslaw, (2006) and Lupa and al., (2008). Also, according to Cabanes (2006), the phosphate removal rate through the salt generally is it between 65.00 and $95.00 \%$. But this value of $89.05 \%$ of phosphate removal rate remains lower than that obtained by Zran and al., 2015. Indeed the treatment done by these authors, on the synthetic aqueous solution gave a phosphate removal rate which is $(95.88 \pm 0.08) \%$. This observation makes sense because the synthetic aqueous solution was none other than distilled water that has been enriched just by $\mathrm{KH}_{2} \mathrm{PO}_{4}$. Otherwise, this difference can be explained by the presence, in wastewater, some disturbing elements of the co-precipitation of phosphate ions. Among these elements could be cited organic compounds and some ions such as chloride, sulfate, carbonate, etc.

Analysis of the results of table 2 shows that the organic material contained in this water has little influence on phosphate removal rate. Indeed, the phosphate removal rate are not evolved considerably between high and low values of COD (Essay 2 and 4 in table 2). This may be due by the fact that the organic material contained in water that is too small to influence the reaction medium so as to disturb the phosphate removal rate contained in this one and further affect the removal rate these ions. However, examining the results of table 2 indicates that the higher concentrations of chloride ions and sulfate ions, are observed at phosphate removal rate (Essay 2 and 4 in table 2). This effective presence of these ions in water to be treated could explain the fact that the phosphate removal rate does not reach the one obtained by Zran and al., (2015).

Table 2:-Results related to treatment of unfiltered wastewater

\begin{tabular}{|c|c|c|c|c|}
\hline & $\begin{array}{c}\text { Cl}^{-} \text {Before } \\
\text { Traitment }(\mathbf{m g} / \mathbf{L})\end{array}$ & $\begin{array}{c}\mathbf{S O}_{\mathbf{4}}{ }^{\mathbf{2}} \text { Before } \\
\text { Traitment (mg/L) }\end{array}$ & $\begin{array}{c}\text { COD Before } \\
\text { Traitment (mg/L) }\end{array}$ & $\begin{array}{c}\text { Phosphate removal } \\
\text { rate }(\boldsymbol{\%})\end{array}$ \\
\hline Essay 1 & 39.70 & 105.36 & 108.00 & $\mathbf{9 2 . 2 0}$ \\
\hline Essay 2 & 75.20 & 167.16 & 132.00 & $\mathbf{8 6 . 0 0}$ \\
\hline Essay 3 & 45.20 & 118.25 & 120.00 & $\mathbf{9 1 . 0 0}$ \\
\hline Essay 4 & 63.10 & 142.88 & 96.00 & $\mathbf{8 7 . 0 0}$ \\
\hline Average & 55.88 & 133.39 & 114.00 & $\mathbf{8 9 . 0 5}$ \\
\hline Standart deviation & 16.28 & 27.36 & 15.49 & $\mathbf{3 . 0 1}$ \\
\hline C.V.(\%) & 29.13 & 2051 & 13.59 & $\mathbf{3 . 3 8}$ \\
\hline
\end{tabular}




\section{Activated carbon treatment}

Studies have shown that whatever experimental conditions, a residual phosphate removal rate remaining in solution after the chemical treatment. The approach in this part was to make an extra treatment with activated carbon (A.C.) to remove residual ions.

Phosphate removal rate after chemical treatment and the final phosphate removal rate after filtering the A.C. are homogeneous (Feinberg, 1996). In fact, the coefficient observed in table 3 is less than 5.00\%. The phosphate removal rate by the A.C. is insignificant. Indeed, according to the averages of the phosphate removal rate from the coupling of two types of treatments, a very small increase was observed on average of $1.75 \%$. It thus appears clear that the A.C. is not an effective adsorbent for phosphate. This may be due by the fact that carbon having been physically active, so there was no positive surface charge to retain phosphate. Thus it will envisage activated carbon with positive surface charges in order to increase the phosphate removal rate.

Table 3:-Results linked to coupling chemical treatment and activated carbon of the unfiltered wastewater

\begin{tabular}{|c|c|c|c|}
\hline & $\begin{array}{c}\text { Phosphate removal rate after } \\
\text { chemical treatment }\end{array}$ & $\begin{array}{c}\text { Finaly phosphate removal rate } \\
\text { after filtering to A.C. }\end{array}$ & C.V. (\%) \\
\hline Essay 1 & 92.20 & 93.20 & $\mathbf{0 . 7 6}$ \\
\hline Essay 2 & 86.00 & 88.00 & $\mathbf{1 . 6 3}$ \\
\hline Essay 3 & 91.00 & 93.00 & $\mathbf{1 . 5 4}$ \\
\hline Essay 3 & 87.00 & 89.00 & $\mathbf{1 . 6 0}$ \\
\hline Average & 89.05 & 90.80 & $\mathbf{1 . 4 0}$ \\
\hline
\end{tabular}

\section{Analysis of the results of treatment of filtered wastewater Chemical treatment}

The value of the coefficient of variation (C.V.) related to the phosphate removal rate after treatment also shows that they are homogeneous. This C.V. is less than $5.00 \%$.

After chemical treatment, the average of phosphate removal rate $(87.75 \pm 3.23) \%$ (table 4$)$ indicates an phosphate removal up to $87.00 \%$ in this real matrix (wastewater). This result is again in agreement with the phosphate removal rates obtained during the work of Babara and Jaroslaw, 2006 and Lupa and al., 2008). Also, according to Frederic (2006), the phosphate removal rate with salts in general it is between 65 and 95\%). However, the phosphate removal rate, remains lower than that obtained by Zran and al., in 2015. This average is also lower than these obtained with unfiltered waste water $(89.05 \pm 301) \%$. It is important to note that after filtration of wastewater, it was found a considerable drop in COD of $90.00 \%$ (Fig. 1). Otherwise, despite this significant COD, the phosphate removal rate is less than that obtained during the treatment of unfiltered wastewater. But, this difference between two phosphate removals is low. The influence of the COD is very little noticed. The study of the effect of organic compounds remains complex (Cabanes, 2006). Nevertheless, the fact that phosphate removal rate obtained when treating unfiltered wastewater are slightly above those of the treatment of filtered wastewater could be explained by the presence of colloids in waterwaste unfiltered. The presence of these species influences positively the phosphate removal rate in this unfiltered wastewater. Indeed the biological flocs can serve as potential supports or place adsorption of certain disturbing elements of the co-precipitation of phosphate. Thus, the more floc formed during the coagulation-flocculation (quantity and size), most elements are trapped, and the phosphate removal rate increases. The important elimination of the COD lets some other disturbing elements of the reaction medium. May be mentioned among other things, chloride ions, sulfate ions, carbonate ions, etc. This is confirmed by the analysis of the results in table 4. The results of this table show a slight decrease of the levels, chloride ions and sulfate ions, in tests performed. Besides this, the examination of the results in table 4 indicates that the low phosphate removal rates are again observed with highest concentrations of chloride ions and sulfate ions. It is important to note that these concentrations are obtained before chemical treatment. Thus, the effective presence of these ions in the wastewater to be treated could confirm again that they are disturbing elements of the co-precipitation of phosphate (Cabanes, 2006).

Table 4:-Results related to treatment of filtered wastewater

\begin{tabular}{|c|c|c|c|c|}
\hline & $\begin{array}{c}\text { Cl }^{-} \text {Before } \\
\text { Traitment }(\mathbf{m g} / \mathbf{L})\end{array}$ & $\begin{array}{c}\mathbf{S O}_{\mathbf{4}}{ }^{2-} \text { Before } \\
\text { Traitment }(\mathbf{m g} / \mathbf{L})\end{array}$ & $\begin{array}{c}\text { COD Before } \\
\text { Traitment }(\mathbf{m g} / \mathbf{L})\end{array}$ & $\begin{array}{c}\text { Phosphate removal } \\
\text { rate }(\%)\end{array}$ \\
\hline Essay 1 & 39.70 & 104.50 & 8.00 & 91.00 \\
\hline
\end{tabular}




\begin{tabular}{|c|c|c|c|c|}
\hline Essay 2 & 75.20 & 160.16 & 12.00 & $\mathbf{8 4 . 5 0}$ \\
\hline Essay 3 & 45.20 & 117.60 & 12.00 & $\mathbf{9 0 . 0 0}$ \\
\hline Essay 4 & 63.10 & 141.00 & 6.00 & $\mathbf{8 5 . 5 0}$ \\
\hline Average & 55.88 & 130.82 & 9.50 & $\mathbf{8 7 . 7 5}$ \\
\hline Standart Deviation & 16.28 & 24.71 & 3.00 & $\mathbf{3 . 2 3}$ \\
\hline C.V.(\%) & 29.13 & 18.89 & 31.58 & $\mathbf{3 . 6 8}$ \\
\hline
\end{tabular}

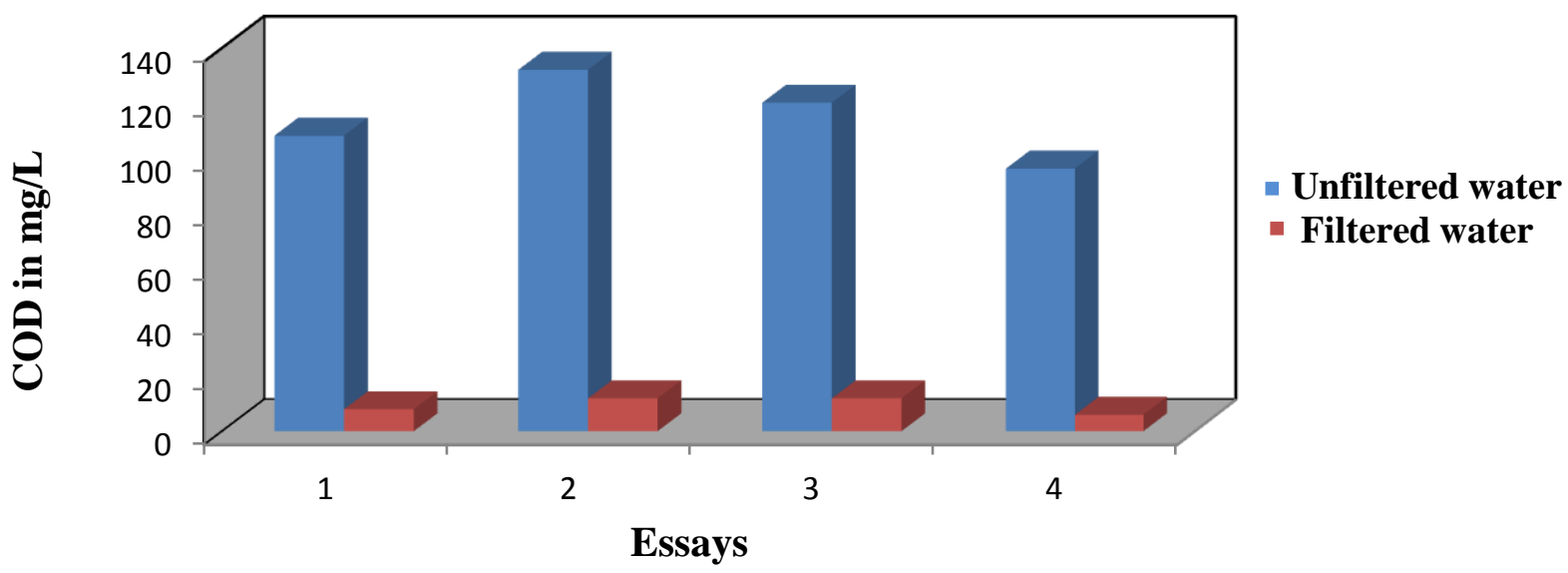

Fig 3:- Representation of the COD of the unfiltered wastewater and filtered wastewater

Activated carbon treatment (A.C.)

The phosphate removal after chemical treatment and the final phosphate removal rate after filtering the A.C. are homogeneous (Feinberg, 1996). Indeed, the coefficient observed in the table is less than $5.00 \%$.)

The phosphate removal rate by the A.C. is still insignificant. Indeed, the refinement in A.C. brings a slight increase on average of $2.00 \%$. This refinement is insignificant. This again confirms the results obtained for the non-filtered wastewater. Also, the surface charges do not allow forming bonds with these ions; which could increase their retention.

From these results it is not advantageous to use this activated carbon as adsorbent phosphate after chemical treatment, both at the level the treatment of unfiltered and filtered wastewaters. Indeed, with the chemical treatment, the maximum phosphate removal is achieved.

Table 5:-Results linked to coupling chemical treatment and activated carbon of the filtered wastewater

\begin{tabular}{|c|c|c|c|}
\hline & $\begin{array}{c}\text { Phosphate removal rate after } \\
\text { chemical treatment }\end{array}$ & $\begin{array}{c}\text { Finaly phosphate removal rate after } \\
\text { filtering to A.C. }\end{array}$ & V.C. (\%) \\
\hline Essay 1 & 91.00 & 92.50 & $\mathbf{1 . 1 5}$ \\
\hline Essay 2 & 84.50 & 86.00 & $\mathbf{1 . 2 5}$ \\
\hline Essay 3 & 90.00 & 92.00 & $\mathbf{1 . 5 5}$ \\
\hline Essay 4 & 85.50 & 88.50 & $\mathbf{2 . 4 4}$ \\
\hline Average & 87.75 & 89.75 & $\mathbf{1 . 6 0}$ \\
\hline
\end{tabular}

Utility to filter the waste water before treatment

The (Various Coefficient) V.C. \% of phosphate removal rate wastewater unfiltered and filtered is less than $5.00 \%$ (table 6). These values of these rates are homogeneous since V.C. show that there are no significant differences 
between these values (Fienberg, 1996). It is important to conclude that the wastewater can be chemically treated without it being filtered.

Table 6:- VC \% between phosphate removal rate of unfiltered water and filtered water

\begin{tabular}{|l|c|c|c|c|c|}
\hline & $\begin{array}{c}\text { Phosphate removal rate } \\
\text { in \% : unfiltered water }\end{array}$ & $\begin{array}{c}\text { Phosphate removal rate } \\
\text { in \% : filtered water }\end{array}$ & Average & $\begin{array}{c}\text { Standart } \\
\text { deviation }\end{array}$ & \begin{tabular}{c} 
V.C. (\%) \\
\hline Essay 1
\end{tabular} \\
\hline Essay 2 & 92.20 & 91.00 & 91.60 & 0.85 & $\mathbf{0 . 9 3}$ \\
\hline Essay 3 & 86.00 & 84.50 & 85.25 & 1.06 & $\mathbf{1 . 2 4}$ \\
\hline Essay 4 & 91.00 & 90.00 & 90.50 & 0.71 & $\mathbf{0 . 7 8}$ \\
\hline
\end{tabular}

\section{Study of the influence of pH on phosphate removal rate}

Phosphate removal of the wastewater, unfiltered and filtered increases with increasing $\mathrm{pH}$ end (table 7). Therefore the $\mathrm{pH}$ has some influence on phosphate removal rate. This is confirmed by the analysis of the two curves of Fig. 4 and 5. These two figures show, in fact, there is a best correlation between the final $\mathrm{pH}$ and removal rate (\%). The coefficients of correlation between these two factors tends to 1 and are of the order of $0.976\left(R^{2}=0.976\right)$ and $0.984\left(\mathrm{R}^{2}=0.984\right)$, respectively for the treatment of wastewater, filtered and unfiltered (Fig. 2 and 3 ). Therefore phosphate removals strongly depend on the $\mathrm{pH}$ in water treatment. It is important to note that the $\mathrm{pH}$ is the determining factor for the coprecipitation of phosphate (Babara and Jaroslaw, 2006; Cabanes, 2006; Lupa and al., 2008).

Table 7:- Results related to the final $\mathrm{pH}$ of each test and phosphate removal rate after chemical treatment

\begin{tabular}{|c|c|c|c|c|}
\hline & Unfilter & Wastewater & Filtered & Wastewater \\
\hline & $\mathbf{p H}_{\text {final }}$ & $\begin{array}{c}\text { Phosphate removal } \\
\text { rate (in \%) }\end{array}$ & $\mathbf{p H}_{\text {final }}$ & $\begin{array}{c}\text { Phosphate removal } \\
\text { rate (in \%) }\end{array}$ \\
\hline Essay 1 & $\mathbf{9 . 8 5}$ & 92.20 & $\mathbf{9 . 6 7}$ & 91.00 \\
\hline Essay 2 & $\mathbf{9 . 1 0}$ & 86.00 & $\mathbf{8 . 9 5}$ & 84.50 \\
\hline Essay 3 & $\mathbf{9 . 7 0}$ & 91.00 & $\mathbf{9 . 5 4}$ & 90.00 \\
\hline Essay 4 & $\mathbf{9 . 2 0}$ & 87.00 & $\mathbf{9 . 1 5}$ & 85.50 \\
\hline Average & $\mathbf{9 . 4 6}$ & 89.05 & $\mathbf{9 . 3 3}$ & 87.75 \\
\hline Standart deviation & $\mathbf{0 . 3 7}$ & 3.01 & $\mathbf{0 . 3 3}$ & 3.23 \\
\hline V.C. \% & $\mathbf{3 , 8 9}$ & 3.38 & $\mathbf{3 . 5 9}$ & 3.68 \\
\hline
\end{tabular}

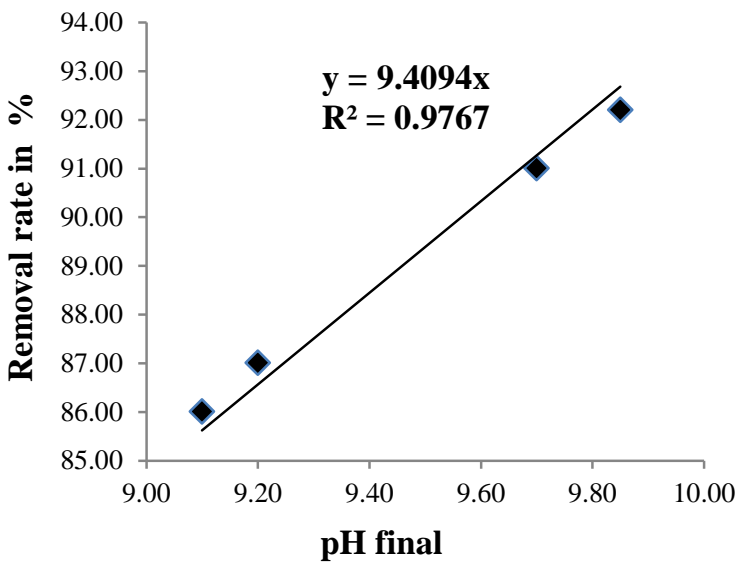

Fig. 2:-Correlation between the phosphate removal and the $\mathrm{pH}$ after chemical treatment of wastewater unfiltered

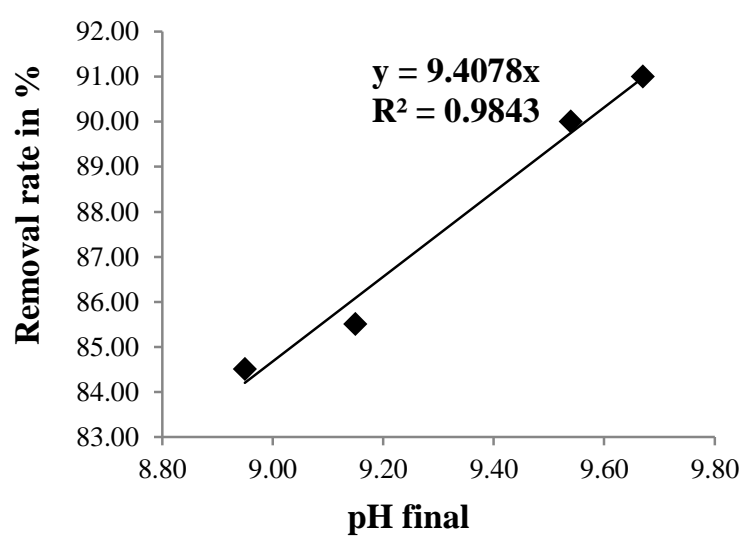

Fig. 3:-Correlation between the phosphate removal and the $\mathrm{pH}$ after chemical treatment of wastewater filtered 


\section{Characteristics of wastewater after treatment}

Analysis of the results table 8 and 9 permit to conclude that the treated water can be discharged into watercourses without major environmental risks, after chemical treatment and after Actived Carbon (A.C.) treatment. Indeed, these values meet all standards CODINORM (2009).

Table 8:- Related results to the residual content in $\mathrm{mg} / \mathrm{L} \mathrm{COD}, \mathrm{Ca}^{2+}, \mathrm{Fe}^{2+}$ and the final $\mathrm{pH}$ after treatment of unfiltered wastewater

\begin{tabular}{|c|l|c|c|c|c|c|c|}
\hline & & Essay 1 & Essay 2 & Essay 3 & Essay 4 & Average & Standart deviation \\
\hline \multirow{2}{*}{$\begin{array}{c}\text { COD } \\
(\mathbf{m g} / \mathbf{L})\end{array}$} & Before traitment & 108.00 & 132.00 & 120.00 & 96.00 & 114.00 & 15.49 \\
\cline { 2 - 8 } & After chemical traitment & 0.00 & 0.00 & 0.00 & 0.00 & 0.00 & 0.00 \\
\hline \multirow{3}{*}{$\begin{array}{c}\mathbf{C a}^{2+} \\
(\mathbf{m g} / \mathbf{L})\end{array}$} & Before Treatment & 126.07 & 137.22 & 186.24 & 172.07 & 155.40 & 24.40 \\
\cline { 2 - 8 } & After chemical treatment & 40.50 & 38.64 & 109,05 & 79.17 & 66.84 & 33.78 \\
\hline $\mathbf{F e}^{\mathbf{2 +}}$ & After A.C. treatment & 22.73 & 24.00 & 72.43 & 54.53 & 43.42 & 24.29 \\
\cline { 2 - 8 }$(\mathbf{m g} / \mathbf{L})$ & Before treatment & 10.35 & 10.45 & 10.25 & 10.37 & 10.36 & 0.08 \\
\hline \multirow{3}{*}{$\mathbf{p H}$} & Before treatment & - & - & - & - & - & - \\
\cline { 2 - 8 } & After chemical treatment & 9.47 & 7.57 & 7.27 & 7.37 & 7.42 & 0.13 \\
\cline { 2 - 7 } & After A.C. treatment & 7.54 & 7.60 & 7.40 & 7.24 & 7.45 & 0.37 \\
\hline \multirow{2}{*}{} & & & & & & \\
\hline
\end{tabular}

Table 9:- Related results to the residual content in $\mathrm{mg} / \mathrm{L} \mathrm{COD}, \mathrm{Ca}^{2+}, \mathrm{Fe}^{2+}$ and the final $\mathrm{pH}$ after treatment of filtered wastewater

\begin{tabular}{|c|c|c|c|c|c|c|c|}
\hline & & Essay 1 & Essay 2 & Essay 3 & Essay 4 & \begin{tabular}{|l|} 
Average \\
\end{tabular} & Standart deviation \\
\hline \multirow{2}{*}{$\begin{array}{c}\text { COD } \\
(\mathrm{mg} / \mathrm{L})\end{array}$} & Before treatment & 8.00 & 12.00 & 12.00 & 6.00 & 8.20 & 36.58 \\
\hline & After chemical treatment & 0.00 & 0.00 & 0.00 & 0.00 & 0.00 & 0.00 \\
\hline \multirow{3}{*}{$\begin{array}{c}\mathrm{Ca}^{2+} \\
(\mathrm{mg} / \mathrm{L})\end{array}$} & Before treatment & 121.37 & 132.62 & 178.32 & 161.57 & 148.47 & 26.13 \\
\hline & After chemical treatment & 42.15 & 49.73 & 89.50 & 85.40 & 66.70 & 24.22 \\
\hline & After A.C. treatment & 25.73 & 27.30 & 52.43 & 48.25 & 38.43 & 13.88 \\
\hline \multirow{2}{*}{$\begin{array}{c}\mathrm{Fe}^{2+} \\
(\mathrm{mg} / \mathrm{L})\end{array}$} & Before treatment & 10.03 & 10.01 & 10.04 & 10.03 & 10.03 & 0.01 \\
\hline & After chemical treatment & - & - & - & - & - & - \\
\hline \multirow{3}{*}{ pH } & Before treatment & 7.49 & 7.90 & 7.69 & 7.76 & 7.71 & 0.17 \\
\hline & After chemical treatment & 9.67 & 8.95 & 9.54 & 9.15 & 9.33 & 0.33 \\
\hline & After A.C. treatment & 7.45 & 7.80 & 7.56 & 7.12 & 7.48 & 0.28 \\
\hline
\end{tabular}

Note: dashes at the online content of $\mathrm{Fe}^{2+}$ mean" track".

\section{Characteristics of precipitates}

The resulting precipitates probably contain apatite as all final $\mathrm{pH}$ exceeds all 9 (tables 8 and 9) after chemical treatment for both unfiltered wastewater for wastewater filtered. According Valsami (2001), the lime reacts specifically with the phosphate ions at $\mathrm{pH} 9$ (tables 8 and 9). Therefore products obtained by the use of iron sulfate may be iron hydroxides such as $\mathrm{Fe}(\mathrm{OH})_{3}$. Indeed the iron phosphates are usually obtained for pH between 6 and 7) (Comeau and Ardelain, 2006 and Molle, 2010; where the nature of the coagulant sulfate hydrated iron seven times $\left(\mathrm{FeSO}_{4} .7 \mathrm{H}_{2} \mathrm{O}\right)$. The phosphate removal has been carried out by the calcium ions. These images (Fig. 4 and 5) obtained by SEM showed that the precipitate has a more or less homogeneous morphology without any particular texture as the results obtained during the chemical treatment of the synthetic matrix. This morphology is consistent with that found by Zran and al., in 2015. 


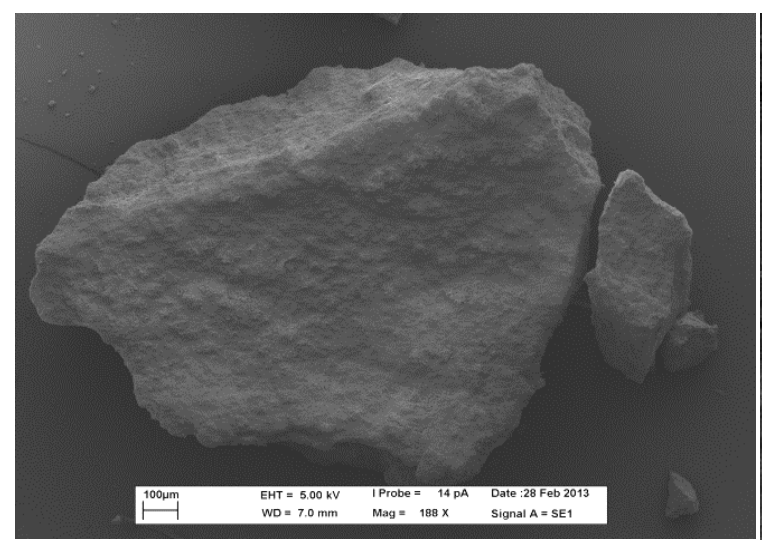

Fig. 4:- SEM macrograph of the precipitate obtained at large-scale

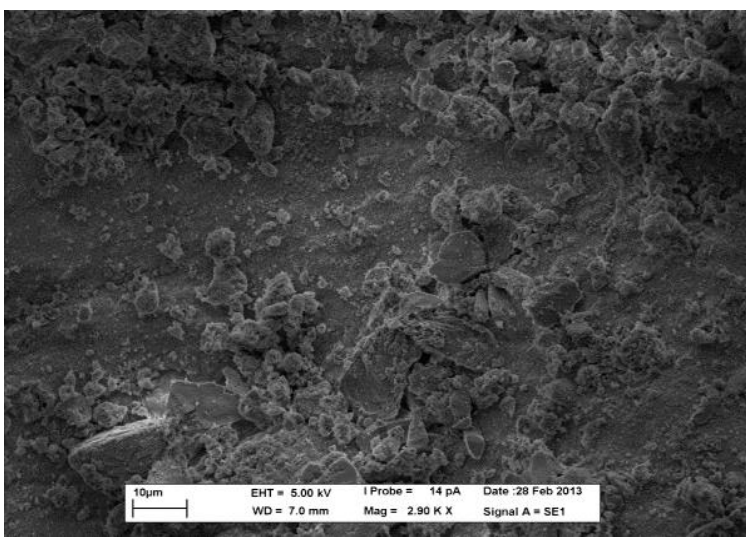

Fig. 5:- SEM micrograph of the precipitate obtained at small-scale

\section{Conclusion:-}

In this work, we note that, for reasons of economy, it is unnecessary to use the additional adsorbent A.C. as phosphate ions after chemical treatment of wastewater. The coupling chemical treatment-A.C. treatment is not necessary for the total removal of phosphate ions from wastewater. Indeed, after the chemical treatment, the contribution of the phosphate removal rate with A.C. is an average of $1.75 \%$ and $2.00 \%$ higher respectively for unfiltered wastewater and filtered wastewater. This contribution is very insignificant. The A.C. is not an additional effective adsorbent for a total phosphate removal rate after chemical treatment of wastewater.

Thus, after chemical treatment, we obtain different quantitatives removal rates that bring the content of phosphate to less than the required discharge standard corresponding to an average yield of $89 \%$ in the wastewater levels and unfiltered filtered wastewater. These results can be considered satisfactory. Then, it was clear from this second step the $\mathrm{pH}$ is an important factor in the co-precipitation of phosphate. This step also showed that urban wastewater can be treated without being filtered. Finally, through this part, this wastewater can be discharged into receiving waters without major environmental risks, after chemical treatment.

The precipitates obtained during the chemical treatment of water types have been characterized, according the $\mathrm{pH}$ end, they would be calcium apatite.

\section{Acknowledgements:-}

This work is the result of a tripartite collaboration of physical chemistry laboratory (lcp-ufr-ssmt) of the félix houphouet-boigny university (ufhb), industrial processes of synthesis, environment and new energies laboratory (lapisen) of the félix houphouet-boigny polytechnic institute (inphb) of yamoussoukro, and of national institute of scientific research (inrs-eau terre et environnement), university of quebec.

\section{References:-}

1. Afnor NF T90-110, (1994): Essais des eaux, dosage des orthophosphates, des polyphosphates et du phosphore total. Recueil de normes Francaises, qualité de l'eau, environnement, pp. 356-366.

2. Barbara G. and Jaroslaw W., (2006): Removal of phosphates and fluorides from industrial wastewater. Elsevier, Desalination, vol. 189, no 1-3, pp. 261-268.

3. Battistoni P., Paci B., Fatone F., Pavan P., (2006): Phosphorus removal from anaerobic supernatants: start-up and steady-state conditions of a fluidized bed reactor full-scale plant. Industrial \& Engineering Chemistry Research, vol. 45, no 2, pp. 663-669.

4. Britton Bi G.H, Yao B. and Ado G., (2006) : Study of Purifying Capacity of the Coconut Carbon from Fibrous Mesocarpe. Journal of Applied Sciences, vol. 6, pp. 2332-2333.

5. Cabanes F., (2006): 'Déphosphatation des effluents: précipitation et valorisation du phosphore'. Thèse de Doctorat de l'Institut National Polytechnique de Toulouse, 219 p.

6. Cemagref, (2004): Traitement du phosphore dans les petites stations d'épuration à boues activées, Document technique FNDAE, no 29, France. 
7. Comeau Y. and Ardelain F., (2006): Déphosphatation des boues de la pisciculture des Alléghanys à Saint Damiende-Bucklan par chaulage. SORDAC, Québec. http://www.mapaq.gouv.qc.ca/siteCollectionDocument/Pecheetaquacult urecommerciales/ SODRAC/36dtt2006_2.pdf.

8. Cordell D., Drangert J-O., White S., (2009): The story of phosphorus: global food security and food for thought. Global Environmental Change, vol. 19, no 2, pp. 292-305.

9. Cote d'Ivoire -Normalisation (CODINORM), (2009). Eaux usées industrielles Spécifications, 1ère édition, NI.

10. Feinberg M., (1996). La valorisation des méthodes d'analyse, une approche chimiométrique de l'assurance qualité au laboratoire. Masson, Paris, pp. 255-271.

11. Hanhoun M., Montastruc L., Azzaro-Pantel C., Biscans B., Freche M., Pibouleau L., (2011): Temperature impact assessment on struvite solubility product: a thermodynamic modeling approach. Chemical Engineering Journal, vol. 167, no 1, pp. 50-58.

12. Jonne K, Ilmar K., Mart S. and Maria P., (2009): Separate and interactive effect of eutrophication and climate variable on the ecosystem elements of the Gulf of Riga. Estuarine Coastal Shelf Sciences, vol. 84, no 4, pp. $509-518$.

13. Kumar P., Sudha S., Chand S., Srivastava V., (2010) : Phosphate removal from aqueous solution using CoirPith activated carbon. Separation Science and Technology, vol. 45, no 10, pp. 1463-1470.

14. Lupa P., Negrea A., Iovi A., Cocheci1 L. and Mosoarca G., (2008): Modelling and automation of the process of phosphate ion removal from waste waters. Brazilian Journal of Chemical Engineering, vol. 25, no 1, pp. $9-17$.

15. Mary H., (2011): Analyse et Modélisation de la précipitation de la struvite: vers le traitement d'effluent aqueux industriels. Thèse de Doctoract de l'Institut Polytechnique de Toulouse, $201 \mathrm{p}$.

16. Mirella D., Galindo C., Barillon R., Halter E., Made B., (2010): Surface reactivity of a- $\mathrm{Al}_{2} \mathrm{O}_{3}$ and mechanisms of phosphate sorption: In situ ATR-FTIR spectroscopy and potential studies. Journal of Colloid and Interface Science, vol. 342, no 2, pp. 437-444.

17. Molle P., Martin S., Esser D., Besnault S., Morlay C., Harouiya N., (2010): Phosphorus removal by the use of apatite in constructed wetland: design recommendations. 12th IWA's International Conference on Artificial Swamp, Venice (Itay).

18. Montastruc L., (2003): Modélisation et optimisation d'un réacteur en lit fluidisé de déphosphatation d'effluents aqueux. Thèse de Doctorat de l'Institut Polytechnique de Toulouse, $273 \mathrm{p}$.

19. Said M., (2012): Elimination simultanée de la pollution azotée et phosphatée des eaux usées traitées, par des procédés mixtes.Cas de la step est de la ville de Tizi-ouzou. Thèse de Doctorat de l'Université Université Mouloud Mammeri de Tizi-ouzou, Algérie, 172 p.

20. SHANABLEH A.M., ELSERGANY M.M., (2013): Removal of phosphate from water using six Al-, Fe, and Al-Fe-modified bentonite adsorbents. Journal of Environmental Science and Health, Francis Taylor, Part A, vol. 48, no 2, pp. 223-231.

21. Shintaro Y., Keisuke F., (2012): Removal of phosphate from solution by adsorption and precipitation of calcium phosphate onto monohydrocalcite. Journal Colloid Interface Sciences, vol. 384, no 1, pp. 128-136.

22. Valsami-Jones E., (2001): Calcium phosphate précipitation. Scope Newsletter, no 41, pp. 8-14.

23. Youcef L.and Achour S., (2005): "Elimination des phosphates par des procédés physico-chimiques". Laboratoire de recherche en hydraulique souterraine et de surface LARHYSS, Université de Biskra, Algérie, no 4, $\quad$ pp. 129-140.

24. Youcef L., Ouakouak A., Boulanouar D., Achour S., (2014): Etude du pouvoir adsorbant du charbon actif en poudre pour l'élimination des phosphates des eaux naturelles. Larhyss Journal, no 17, pp. 35-46.

25. Zhang L., Zhou Q., Liua J., Chang N., Wana L., Chen J., (2012) : Phosphate adsorption on lanthanum hydroxide-doped activated carbon fiber. Chemical Engineering Journal, vol.185- 186, pp. 160- 167.

26. Zhong-Liang S, Fu-Meil L., Shu-Hua Y., (2011): Adsorptive removal of phosphate from aqueous solutions using activated carbon loaded with Fe(III) oxide, NEW CARBON MATERIALS, vol.26, no 4, pp. 299-306.

27. Zhou Q., Wang X., Liu J., Zhang L., (2012): Phosphorus removal from wastewater using nano-particulates of hydrated ferric oxide doped activated carbon fiber prepared by Sol-Gel method. Chemical Engineering Journal, vol. 200-202, pp. 619-626.

28. Zran E., (2015): "Procédés d'élimination du phosphore dissous dans les eaux usées". Thèse unique de Doctorat de l’Université Felix HOUPHOUET- BOIGNY, Abidjan, 151 p.

29. Zran E., Yao B., Trokourey A., Yobouet a. and Drogui P., (2015): An optimized pathway for phosphate ions removal from aqueous solution based on experimental design methodology. International Journal of Environmental Science and Technology, vol.12, no 10, pp. 3117-3124. 